\title{
Reflexões quanto à literatura marginal brasileira: comparando Ferréz a sua tradição literária
}

\author{
Vinícius Gonçalves Carneiro ${ }^{1}$
}

A associação do adjetivo marginal à literatura produziu diferentes empregos e significados, dando origem a uma ampla gama de sentidos. Conforme Érica Peçanha do Nascimento, isso ocorre porque "marginal" serve simultaneamente para designar publicações literárias produzidas e veiculadas à margem do sistema editorial brasileiro; que não pertencem ou que se opõem aos cânones estabelecidos; que são de autoria de escritores originários de grupos sociais marginalizados; ou que tematizam o que é peculiar aos homens e espaços tidos como marginais. Com as edições da revista Caros Amigos de 2001, 2002 e 2004, ${ }^{2}$ somou-se a conotação de ação coletiva (Nascimento, 2006, p. 1). Haveria, contudo, algum traço formal que caracterizaria a produção desses autores, distinguindo-os de outras obras contemporâneas ou promovendo ilações com a tradição literária? A proposta neste artigo é refletir sobre alguns aspectos formais de Manual prático do ódio, de 2003, tentando trazer à tona contribuições ligadas ao fenômeno literário em questão.

O segundo livro de Ferréz possui um narrador onisciente que relata a trajetória de um grupo de criminosos formado por Lúcio Fé, Celso Capeta, Aninha, Mágico e Neguinho da Mancha na Mão. Seu objetivo é realizar um assalto na tentativa de escalar uma etapa na carreira do crime organizado. Estes e outros criminosos, assim como moradores da favela e sujeitos que, por um motivo ou outro, passam pela periferia, são apresentados em segmentos sucessivos do romance. Compõem-se, dessa maneira, instantâneos de quem transita na periferia: personagens que vêm de fora para passar por ali; que partem dela para depois voltarem; ou que estão restritas a seus limites. O entrelaçamento das histórias finda por evidenciar uma cartografia rizomática da região. Tal centralidade tem vinculações fortes com a conexão afetiva entre a voz

\footnotetext{
${ }^{1}$ Doutor em teoria da literatura e professor leitor na Universidade Paris-Sorbonne - Paris IV, Paris, França. E-mail: vinicius.gui@gmail.com

${ }^{2}$ Para mais informações sobre essa publicação, ver Zibordi (2004).
} 
de quem conta e o espaço, o que origina, de acordo com Damascena (2015), um "narrador territorial".

\section{Dois registros, um discurso}

Ter como condutor da história alguém que fala a língua da sua terra é peça fundamental para compreender o modus operandi do narrador. Porém, para chegar a esse momento culminante da representação da oralidade na prosa brasileira, houve um longo caminho a ser percorrido na nossa tradição literária. Luís Gonçalves Bueno de Camargo aponta que esse percurso remonta ao romance de 30 , sendo um dos pontos de virada Menino de engenho, de José Lins do Rego:

José Lins quer - e pratica em seus romances, é bom que se diga uma língua "natural", que possa servir de verdadeira língua franca literária, ou seja, que possa constituir um instrumento de comunicação em nosso ambiente literário (Camargo, 2001, p. 69).

De acordo com Camargo, a obra de José Lins atesta um momento em que a literatura brasileira distancia-se de uma oralidade exotizada do pobre. É quando a construção discursiva emitida por desfavorecidos e desvalidos não é mais passível de estigmatização.

Em Manual prático do ódio, percebemos que a transcrição de um registro oral passa para outro patamar. Está em jogo o empoderamento do narrador da periferia, cujo discurso está repleto de gírias e expressões locais, comumente apontadas pelos críticos como elementos que o unem inexoravelmente ao território. Todavia, é importante ressaltar que há uma diferença entre a palavra dos sujeitos retratados no romance e a de quem lhes dá vida. Isso se torna manifesto quando cotejamos a linguagem do narrador com a das personagens:

Régis colocou o copo com caldo de cana vagarosamente no balcão da barraca e antes de ir olhou para a blusa de Nego Duda, tentou notar algum volume, não viu e foi para o canto, mas precavido fingiu que ia coçar a barriga e colocou a mão no revólver, só tirou a mão quando Nego Duda começou a lhe falar do ocorrido.

- O barato é o seguinte, tô com um esquema bom, pra fazer um maluco.

- Quem que é? - perguntou Régis colocando a mão dentro da cintura novamente, com o temor de Nego Duda falar que era ele, se fosse esse o caso, quem puxasse primeiro fritaria o outro. 
- Você num conhece, mora longe.

- Sério? - disse Régis tirando a mão da cintura novamente.

- Mas num é isso que interessa, o que pega é o seguinte, o maluco quer dar cinco pau pra o outro ir pro inferno, só que quero saber com você como vou fazer isso?

- Fazendo, porra! - respondeu Régis com ironia.

- Cê tá me zuando, eu sei, mas num sei se pega alguma coisa, o maluco mora lá no Brás, pode ser encrenca, num conheço a área, truta.

- Peraí, deixa eu pensar... Faz assim, ó, dá um psicológico no cara, nesses caso, força num é nada, você tem que usar a sapiência.

- O quê?

- Esquece, vou resumir procê, sabe o que você faz? Marca com ele, fala pra ele levar os cinco mil e a foto com todo o endereço do cara que ele quer ver furado, quando o otário mostrar o dinheiro, você quebra ele que tá mais perto e não precisa de ir pro Brás matar o que tinha que morrer, assim cê num corre risco fazendo merda na área dozotro.

- Mas o maluco não vai pagá adiantado, eu acho.

- Paga sim, fala que é garantido, e que você num vai poder voltar pra área tão cedo, diz que quem garante você é o Valdinei que cuida da padaria, que ele é pé de pato e todo mundo confia nele.

- Pode crê, Régis, ó, vou dá dessas memo, e depois ele num vai nem poder falar com o Valdinei da padaria, afinal difunto num fala, né não?

- É nessas memo, jão, tu tá ficando malandro.

- Valeu, Régis, mó adianto cê me deu.

- Que nada Nego Duda, a vida é assim, a gente tem que ensinar pra quem num sabe.

- Vai se fodê, o seu psicológico que é foda mesmo, mas aí, o que posso te dá pela ideia?

- Dá nada não jão, se um dia eu precisar você me ajuda, irmão!

- Firmão, Régis, num vô esquecê não. Aí!, vai na paz.

- Falou, Nego Duda, e marca pra pegar o dinheiro no escadão do colégio que é mais sossegado, dá só um no globo do otário, tá ligado?

- Por quê?

- Mas é jão, mesmo! É que se o maluco reagir você tomba ele lá mesmo, entendeu loque? Lá quase num passa ninguém, principalmente à noite, e ainda mais final de semana. 
- Firmeza, vou fazer isso, ó! (Ferréz, 2014, p. 23-24, grifo nosso).

Alguns termos foram destacados para evidenciar a utilização de uma linguagem que, seja no diálogo, seja nos comentários do narrador, distancia-se da norma culta. Estamos falando de vocábulos como "barato", usado no sentido de negócio, "fazer" e "fritar", no sentido de assassinar, e de grafias como "procê", "dozotro", "difunto", "memo", "cê" e "esquecê". Segundo Rodriguez, os registros de uma linguagem oral, cuja escrita nomeou como pseudofonética, e a abundância de termos recorrentes nas comunidades são matizes relevantes na concepção do escritor e do leitor das periferias (2004, p. 61). Entretanto, tendo em vista que na obra posterior de Ferréz, Deus foi almoçar (2012), a linguagem é distinta, propomos pensar não em termos da formação do autor, mas do narrador. Assim, tanto o artista não fica mais limitado a análises que o acoplam a uma ideia de literatura marginal quanto o narrador de Manual prático do ódio não é mais a imagem e semelhança do seu criador. Em entrevistas, o próprio Ferréz já alerta sobre isso:

CL [Canto dos Livros]: Na esteira da pergunta anterior, você se sente amarrado a escrever livros e textos presos ao estilo e temática de Capão pecado?

F [Ferréz]: Não. Quem ler o Ninguém é inocente em São Paulo já vê alguns contos de ficção total, e fora do tema de periferia. Esse livro novo [Deus foi almoçar] não tem nada de periferia, o tema eu já moro nele, não preciso carregá-lo (Ferréz, 2011).

Notemos então que, se o enunciador maior do segundo romance de Ferréz compartilha de uma maneira de falar característica, ratificadora do local do qual fala (elemento central para descortinar um jogo de dominação social mais complexo), não é menos verdade que a utilização desses modos de usar a língua portuguesa é mais frequente nos diálogos das personagens. Isso poderia nos levar a crer que o narrador diferencia-se, por meio deste procedimento, dos seres de quem fala. Como consequência, uma construção discursiva teria as condições para contar a história, enquanto outra não seria autônoma para tanto. Verdade seja dita, o pretenso distanciamento é um equívoco. Vejamos uma das descrições de Eliana, dona de casa e mulher de Régis na trama:

$\mathrm{O}$ que lhe dava tanto medo era a solidão, quando terminava os deveres domésticos, ela vinha devagar, bem rasteira e de repente dominava toda a situação. Sentia o vento frio lhe bater no braço, mas as janelas estavam todas fechadas, Eliana sentia em seus 
pequenos dedos brancos e trêmulos a pontada fria do que logo a abraçaria inteira, já sentia em seus delicados pés o frio insuportável da ausência. Agora sabia que ela estava ao seu lado, provavelmente bem encostada em suas costas, com a boca em sua nuca, querendo envolvê-la por completo (Ferréz, 2014 p. 43).

Tal delicadeza melancólica faz parte desse homem que convive com atrocidades e descasos de uma vida sem benesses. Estamos diante de uma descrição em nada oralizada ou exotizante, que consta em textos anteriores, ligados a uma ideia lato sensu de literatura marginal. De 1997, Cidade de Deus (cujo autor, Paulo Lins, é igualmente oriundo do gueto) possui, em meio a descrições da violência do cotidiano prenhe de gírias, expressões e referências de um mundo excluído de direitos, um estilo semelhante, embora de nuances sinistras:

Os leiteiros já haviam passado. A garotada assistia National Kid. Os que não tinham televisor iam para a janela do vizinho apreciar as aventuras do super-herói japonês. O sol já havia se distanciado da serra do Grajaú, um vento raivoso sustentava as pipas que se cruzavam no céu. Alternadamente pequenos nevoeiros de poeira vermelha nasciam $e$ morriam ao longo das ruas de barro batido, as crianças uniformizadas que saíam dos colégios enchiam os olhares. Já dera meio-dia (Lins, 2012, p. 20, grifo nosso).

Sem a mesma variação estilística, tal empoderamento do narrador já se identifica em Quarto de despejo, de 1960, de Carolina Maria de Jesus:

Quando puis a comida o João sorriu. Comeram e não aludiram a cor negra do feijão. Porque negra é a nossa vida. Negro é tudo que nos rodeia. [...] O céu é belo, digno de contemplar porque as nuvens vagueiam e formam paisagens deslumbrantes. As brisas suaves perpassam conduzindo os perfumes das flores. E o astro rei sempre pontual para despontar-se e recluir-se. As aves percorrem o espaço demonstrando contentamento. A noite surge as estrelas cintilantes para adornar o céu azul. Há várias coisas belas no mundo que não é possível descrever-se. Só uma coisa entristece: os preços, quando vamos fazer compras. Ofusca todas as belezas que existe. A Theresa irmã da Meyri bebeu soda. E sem motivo. Disse que encontrou um bilhete de uma mulher no bolso do seu amado. Perdeu muito sangue. Os médicos diz que se ela sarar ficará imprestável. Tem dois filhos, um de 4 anos e outro de 9 meses. (Jesus, 1993, p. 39) 
Com a ressalva dos problemas de mediação de Audálio Dantas, ${ }^{3}$ deparamo-nos aqui com uma visão de mundo refinadamente triste, de evasão, que insurge sobre os escombros da existência. $\mathrm{O}$ artifício serviria para retratar esses "representantes de sentimentos e sentidos profundamente identificados entre si", refugiados "na semelhança de uma falta difícil de definir, da dor" (Hollanda, s.d.). Definições referentes a Manual prático são, assim, perfeitamente expansíveis a Cidade de Deus e Quarto de despejo.

Em relação à oralidade, esta sugere algo que supera uma simples grafia modificada, mais próxima da elocução real, exatamente como podemos entender em termos como "jão". Em diálogo com Lúcio Fé, o cobrador de uma lotação contribui à elucidação:

- Tá vendo esses jão aí? Num quiseram sentar não ó! Vai sujar o terninho, mas sabe o que eles vão fazer hoje? Estacionar carro de rico a noite toda, e fica dando uma de advogado, esses jão, viu! É jão de Manejão, lá no Rio todo mundo fala mané, aqui é jão (Ferréz, 2014, p. 35, grifo nosso).

Não se trata apenas da contração de "Manejão", e sim da constituição de outro vocábulo, que tem outros sentidos e usos. É o mesmo caso de "nóis", de presença tímida no romance, mas não menos ilustrativa:

- Firmeza, Modelo. Aí, liga nóis se precisar, hein, vou falar, quando cê quiser trombar aqueles maluco lá de cima, liga eu, por favor, cê tá ligado (Ferréz, 2014, p. 22, grifo nosso).

$\mathrm{O}$ "eu" teoricamente daria lugar ao pronome plural de modéstia ou majestático. O seu sentido, contudo, é transformado pelo acréscimo de "i". A palatalização faz "nóis" superar a finalidade retórica e referir-se a uma comunidade. O sujeito, embora sozinho, está engajado ao coletivo, ao território, e, com isso, a certos princípios éticos e morais. Além de expressões e ditos associados ao padrão falado no gueto, desprestigiado quando longe de seu locus enunciativo, também novos sentidos forjam a língua do narrador e das personagens de Manual prático do ódio.

A voz que enreda as tramas ora usa os padrões da norma culta, ora vale-se da maneira de falar dos moradores da periferia. Em si híbrida, mistura dois universos em nada excludentes, o daqueles cuja base

\footnotetext{
${ }^{3}$ João Cezar de Castro Rocha discute os problemas de mediação em Quarto de despejo (2007, p. 52-53).
} 
cultural é o hip-hop e o daqueles com lastro de leitura, como Paulo, sobre o qual discorremos adiante. É como se a velha Totonha de Menino do engenho tomasse afinal e definitivamente a palavra, usufruísse dos modos da casa-grande e explicasse, através de diferentes trajetórias, o funcionamento do sistema. Trata-se da confirmação de uma possibilidade de construção discursiva marginal. Parafraseando Spivak (2010), enfim o subalterno poderia falar.

\section{Conceitos e denominações}

Como o narrador está atrelado à favela e possui características semelhantes às figuras dramáticas retratadas, não podemos cair na tentação de unificar as falas e afirmar que existe "uma voz da periferia" ou "uma voz coletiva" em Manual prático do ódio, embora tal definição seja corroborada por outros textos e autores. Estamos falando de Capão pecado (2000), no qual há uma espécie de desaparição elocutória do eu ${ }^{4}$ para o protagonismo do espaço da subalternidade, já que se acumulam ao relato fotos e escritos de outros artistas. Esse projeto estaria aliado à ideia de obra grupal, em que o conjunto seria mais relevante que o espectro individualizado e individualizante do autor (logo, do narrador, representante de um todo). A união faria a força para se erigir enunciados sem mediações. Cada uma das cinco partes do livro é iniciada por colaborações de pessoas ligadas à periferia, como Mano Brown, Cascão, Outraversão, Negredo e Conceito Moral. Somam-se a isso 37 fotografias do bairro de Capão Redondo, divididas em duas séries, coloridas e em preto e branco, mostrando a pobreza e a precariedade da região que

[n]ão só descrevem o espaço físico (ou geográfico), mas sua singularidade, sua condição, seu anonimato, seu abandono e, ambiguamente, a felicidade estampada em faces de crianças, jovens e adultos moradores (Velloso, 2007, p. 90).

Pode-se acessar a carga informativa antes mesmo de abrir a brochura. Observemos a descrição de Mário Augusto Medeiros da Silva: A capa traz, sobreposto, um garoto avermelhado de bermuda, touca e braços abertos, com uma tarja preta nos olhos (o que se

4 Em Mallarmé, a desaparição elocutória do eu seria a ascensão da linguagem; em Ferréz, a do território. 
tornou símbolo da figura delinquente do menor), segurando uma pistola numa das mãos. A postura é de desafio, haja vista a posição da cabeça, com o queixo levantado. Ao fundo desta imagem em primeiro plano, uma fotografia amarronzada de casas em alvenaria precária, barracos e telhados de uma favela. Capão Pecado, se escreve em letras vermelhas estilizadas, bem como o nome do autor, logo abaixo (Silva, 2011, p. 399-400).

Façamos o cálculo: o arranjo interno da publicação mais o nome do bairro devidamente modificado na capa mais o pseudônimo mais a mutação das personagens em um todo territorial mais a violência daqueles à margem mais o fato de utilizar como locação um lugar pouco abordado na literatura brasileira contemporânea. ${ }^{5}$ Como resultado, o apagamento da imagem do autor e o surgimento da literatura marginal. Com efeito, há contribuições inestimáveis oriundas da utilização do adjetivo como chave hermenêutica. Destaquemos o já citado estudo da antropóloga Érica Peçanha do Nascimento "Literatura marginal": os escritores da periferia entram em cena (2006). Há ainda críticos literários renomados que promovem desdobramentos do conceito, como Flora Süssekind (2003), a qual prefere falar em "reterritorialização etnográfica" ou "ficção neodocumentalista", e João Cezar de Castro Rocha (2005; 2007), que opta por "dialética da marginalidade" e "projeto coletivo". Já o sociólogo Mário Augusto Medeiros da Silva (2011), acima citado, escolheu o termo "literatura do insólito" para abordar o tema. Em todos os casos, ${ }^{6}$ busca-se uma especificidade da literatura cujos grandes nomes seriam Ferréz e Paulo Lins e na qual a voz individual apaga-se para a emergência do coletivo e do espaço.

Na contracorrente desses estudos, de incomensurável valia, nossa tendência é particularizar o romance de 2003, desfocando-o por vezes do território, por mais paradoxal que pareça. Comecemos pela mudança antroponímica: trata-se de um procedimento similar ao empregado por rappers, é claro, mas também por poetas da geração da poesia marginal

\footnotetext{
${ }^{5}$ Se o pobre não é minimamente representado na literatura brasileira contemporânea, não podemos afirmar que o local onde majoritariamente mora o seja. Para mais informações sobre a personagem no romance brasileiro contemporâneo, ver Dalcastagnè (2005).

${ }^{6}$ Há ainda pesquisadores menos renomados que se valem de outras denominações, como "literatura de mutirão" (Rodriguez, 2004), "realismo atolondrado" (Carvalhal, 2014), "potência coletiva" (Mongim, 2012), "narrador territorial” (Damascena, 2015).
} 
dos anos 1970 (como Ledusha, Chacal e Cacaso), citado no "Manifesto de abertura: Literatura Marginal Terrorismo Literário":

O mimeógrafo foi útil, mas a guerra é maior agora, os grandes meios de comunicação estão ai, com mais de $50 \%$ de anunciantes por edição, bancando a ilusão que você terá que ter em sua mente (Ferréz, 2005b).

Logo, pseudônimos nem são inéditos no sistema literário brasileiro nem exclusivos dos guetos. Além do mais, ao aparecer na capa de Capão pecado (2000), a prática não está apenas associada à criação de um universo ficcional, mas à própria organização no livro das fotos e textos de terceiros. Sendo assim, por mais que tenha tido a contribuição de vários agentes, o coletivo está subordinado a uma lógica autoral. Para corroborar a constatação, as contribuições somem na edição da Objetiva (Ferréz, 2005a) e não estão presentes nas outras prosas longas do escritor.

Marca da primeira edição de Capão pecado, a mescla entre literatura, música - confira os paratextos dos rappers e o álbum Determinação, de Ferréz (2003) - e artes visuais - vide as fotografias que compõem o volume na edição da Labortexto -, somada ao manifesto (típico de movimentos, por mais que se negue a alcunha), não é novidade na literatura brasileira. A junção é o epicentro estético do tropicalismo do fim da década de 1960, que repercutiu na poesia marginal da década seguinte. Os movimentos mais antigos, no entanto, tiveram vida breve, ${ }^{7}$ e seus artistas não foram analisados em uníssono, a partir do mesmo aporte epistêmico. Ao contrário, a grande riqueza de sua arte advém da tensão singular de suas produções.

Além disso, não parece ser um argumento dos mais fortes a ausência de grandes protagonistas como um indício da coletivização enunciativa e, por conseguinte, da marginalidade dessa literatura. Quando se faz tal afirmação, não se está negando a diluição elocutória em Capão pecado, semelhante à de Cidade de Deus. No best-seller de 1997, há novamente a exposição de uma gama de personagens periféricos, mas a onisciência narrativa serve para contar a história de uma favela carioca. Distinguese então da proposta sincrônica de Capão pecado, que a entende mais

\footnotetext{
${ }^{7}$ O tropicalismo iniciou-se em 1967 e terminou com o exílio de Gilberto Gil e Caetano Veloso, em 1969. A geração mimeógrafo, da segunda metade da década de 1970, teve seu fim quando boa parte dos autores foi assimilada pelo mercado editorial, publicando notadamente pelas editoras Brasiliense e L\&PM.
} 
como organismo; ou da trama criada para exibir os mecanismos de exploração que levam à violência, como em Manual prático do ódio.

Sem dúvida, há traços de coletividade em Ferréz e Paulo Lins, mas não suficientes para sustentar o adjetivo "marginal" como guardachuva conceitual de textos tão díspares. A referência ao nome do bairro nos títulos ou a quase onipresença do local evidenciam a conexão das personagens ao espaço, mas não garantem o advento de uma voz coletiva. Nas duas produções com referências aos bairros, por exemplo, as construções discursivas porosas estão intimamente vinculadas a projetos que falam de localidades metropolitanas desprestigiadas, mas esses projetos possuem estratégias enunciativas com determinados intuitos ficcionais, não podendo ser vistos como fruto de um mesmo fenômeno literário. ${ }^{8}$ Por mais que pareçam detalhes, tais variantes são primordiais para que não se diminua a prosa de Ferréz a uma denúncia artística em mutirão. Como contraveneno, investiguemos as particularidades de Manual prático do ódio.

\section{Manual prático do ódio na tradição literária brasileira}

Se em Deus foi almoçar, Calixto, personagem da classe média, é a razão de existir da obra, na publicação anterior de Ferréz temos Régis, protagonista cujas atividades e movimentos no enredo são os mais decisivos. Bandido que atira para matar, ele é o fio condutor da história (Hollanda, s.d.). Seu objetivo: que seu "bolso estivesse sempre cheio" (Ferréz, 2014, p.37). Não se trata de um justiceiro ou de um vilão patológico, mas sim de um profissional do crime. Por isso, é identificado pelos outros criminosos como uma pessoa distinta, de conceito. A lógica profissional, contudo, faz dele um homem atormentado, pois, para não ser preso (isto é, ser impedido de trabalhar), assassinara a única mulher que amara. O ofício justificaria a impossibilidade de uma vida afetuosa: não obstante um casamento de dez anos com Eliana, transborda indiferença em relação à esposa e oprime a amante; ama o filho, é verdade, mas não demonstra carinho.

\footnotetext{
${ }^{8}$ A obra de Paulo Lins em questão, é bom lembrar, passou a ser acompanhada do adjetivo "marginal" sobretudo após as edições sobre o tema na revista Caros Amigos, mesmo que o autor seja oriundo de outro contexto periférico e tenha outra trajetória no sistema literário, outra proposta estética e outra relação com a sua comunidade de origem.
} 
Porém, no final das contas, seus atos apontam uma lógica que não difere muito da de Modelo, delinquente cruel. Em dado momento, a figura central monta uma cilada para matar e roubar o lucro do delito cometido por Nego Duda, jovem e intempestivo ladrão que poderia causar-lhe problemas. Se Nego Duda é uma ameaça para Régis, Régis é uma ameaça para Modelo. Estamos diante do mesmo princípio que Modelo vale-se para dar o golpe na quadrilha de Régis. As diferenças são as cifras envolvidas (Régis rouba de Nego Duda muito menos que Modelo de Régis), os requintes de crueldade de Modelo, cuja "maldade [...] já era conhecida" (Ferréz, 2014, p. 144) e a atitude de quem conta. O que acontece na obra é que, tomando Régis como agente principal, somos induzidos a regozijarmo-nos com a morte de Modelo, cena digna de filmes de Lars Von Trier, numa das inúmeras em que se flagra o momento de ódio no romance (Hollanda, s. d.).

Ambos os criminosos, por mais que estejam em campos opostos na diegese e apresentem comportamentos em intensidades desiguais, trabalham com um idêntico axioma capitalista contemporâneo, levado às últimas consequências: se eu não tiro vantagem do próximo, é ele quem vai tirar vantagem de mim. Pensar suas trajetórias em paralelo explicita como as tramas caminham na direção de estabelecer um novo olhar sobre seu território, uma vez que a partir delas se descortinam as veredas da opressão do morador marginalizado (criminoso ou não), explorado e excluído do mercado de bens simbólicos e inexoravelmente limitado pelo apartheid brasileiro. Lembremos que os assaltantes invejam a vida de Mágico:

Régis entra no carro [...] pega o caminho para a casa do Mágico [...]. O lugar é bonito, Morumbi Sul não é pra qualquer um morar, ainda mais em casa, um apartamento até que dá, mas casa é só pra quem tem, Régis sabe disso e sempre que chega à casa do parceiro cresce os olhos, queria ter aquilo, não entende como ele conseguiu tanto dinheiro, os pensamentos voam, minutos depois de chegar, decide entrar, a garagem já estava aberta, entra com o carro na garagem, sobe as escadas para o escritório e para no meio da subida, avista Mágico descendo, trocam cumprimentos e Mágico diz que eles têm que conversar na garagem, pois sua esposa está com visitas, Régis começa a voltar (Ferréz, 2014, p. 81, grifo nosso).

Não é que seja impossível afastar-se da periferia: não se sabe nem como sair de lá. O conhecimento é interdito, e o conflito interno se estabelece em beneficio dos que estão alheios à comunidade. $\mathrm{O}$ 
narrador, nesse momento, exerce papel fundamental, permitindo-nos compreender o raciocínio do favelado, cujo entendimento de mundo é econômica e socialmente circunscrito. Por vezes, trata-se de uma postura moralista, pois o mediador inunda-nos com seus julgamentos e conclusões. Comportamento similar consta em Capão pecado, conforme Mário Augusto Medeiros da Silva:

A esfera moralista está presente também num narrador em terceira pessoa que julga cada ação operada em Capão, inclusive do personagem principal. Sendo esta uma característica desse tipo de narrador onisciente, ela se acentua nos julgamentos e ensinamentos que procura passar. [...] Ferréz [...], em Capão Pecado, se vê compelido a usar seus personagens para passar mensagens que, talvez, criem um circuito literário criativo mais restrito. Em Ferréz e Capão Pecado, literariamente ao menos, existem crenças em saídas e a periferia é capaz de gerar um projeto coletivo. Aspectos disso estão afirmados pelo autor (Silva, 2011, p. 404-405).

Em Manual prático do ódio, igualmente ocorrem as tomadas de posição condicionadas a certos princípios, a priori ensinamentos destinados a uma marginalidade. Opinar e criticar está no cerne da estrutura de ambos os narradores. A tendência pedagógica busca explicar as sucessões de acontecimentos referentes aos personagens e seus significados:

Na mesma calçada passava Rodrigo, aluno do colégio São Luís, localizado nos Jardins, o aluno passou despercebido, pois tinha trocado o uniforme por roupas mais simples para ir embora para casa, todos na escola passaram a adotar a prática depois que alguns colegas foram assaltados no percurso entre a casa e a escola, as vítimas eram sempre jovens de 14 a 16 anos, e os executores dos furtos também tinham a mesma idade, a única diferença entre os jovens que roubavam e os roubados era o muro social que divide o país (Ferréz, 2014, p. 32, grifo nosso).

A presença de conjunções como "pois", "porque" e "assim como" em finais de parágrafos comprovam a disposição por conclusões cabais, muitas vezes redundantes. Para Paulo Roberto Tonani do Patrocínio, a afinidade do autor com o movimento hip-hop influiu para que a sua produção artística fosse "um instrumento pedagógico de formação de uma consciência própria do leitor", "um veículo de intervenção social através do texto" (2010, p. 109). Isso seria reforçado pelo "Manifesto de abertura: literatura marginal - Terrorismo literário", de 2005, no qual se 
evidencia o público com quem se almeja o diálogo: "A revista é feita para e por pessoas que foram postas à margem da sociedade" (Ferréz, 2005b, grifo nosso). O moralismo apontado por Silva, desse modo, não está distante da proposta pedagógica identificada por Patrocínio.

Todavia, tal práxis narrativa está presente, e não por acaso, na prosa brasileira da primeira metade do século passado, para nos atermos a posturas semelhantes. $\mathrm{O}$ romance de 30 de caráter regionalista tinha como ideia básica mostrar o Brasil para os brasileiros, explicitando uma realidade antes desconhecida. Vejamos o seguinte trecho de Menino do engenho:

$\mathrm{O}$ costume de ver todo dia esta gente na sua degradação me habituava com a sua desgraça. Nunca, menino, tive pena deles. Achava muito natural que vivessem dormindo em chiqueiros, comendo um nada, trabalhando como burros de carga. A minha compreensão da vida fazia-me ver nisto uma obra de Deus. Eles nasceram assim porque Deus quisera, e porque Deus quisera nós éramos brancos e mandávamos neles. Mandávamos também nos bois, nos burros, nos matos (Rego, 2014, p. 108).

O interior do país dos anos 1930 e a periferia das metrópoles da passagem do século XX ao XXI são representados com perspectivas de legitimação travestidas em análogos comportamentos moralistas. Se escritores como José Lins do Rego estavam respaldados em contar suas histórias por terem vivido em fazendas e engenhos de cana, criando discursos a ele conectados umbilicalmente, o mesmo ocorre com Ferréz, legitimado a escrever sobre o tema porque dele oriundo. Seguindo o raciocínio, por este critério Capão pecado e Manual prático do ódio estão tão ou mais próximos de Menino de engenho que de Cidade de Deus.

Especificamente em Manual prático do ódio, as personagens vão sendo apresentadas por meio de seus atos, pensamentos e reflexões, grande parte oriundos do entrecruzamento das vozes do narrador e de quem passa, de algum modo, pelo território. Esse narrador, centrado no conjunto de moradores, objetiva esclarecer a exploração dos seus iguais por meio de parágrafos e capítulos metodicamente contundentes. De acordo com a sua compleição, fala-se forte para se fazer ouvir. O tom pedagógico, portanto, está ligado a mostrar um perímetro urbano de um ponto de vista peculiar e desconhecido, advindo de um espaço raramente utilizado como locação na nossa tradição literária. Ou seja, o ineditismo reside nas características da enunciação, a qual deve ser investigada em si. 


\section{Por dentro do Manual}

Para comportar a complexidade de eventos e atores no romance, o artifício encontrado é o emprego do discurso indireto livre. Recorrente em Capão pecado e, em menor escala, em Deus foi almoçar, ${ }^{9}$ o recurso faz de Manual prático do ódio quase um "labirinto de pensamentos", conforme termo de Renato Souza (2010, p. 125):

Carol havia levado os dois filhos para a escola, o serviço de transporte escolar não era confiável, segundo a conversa que tivera com o marido, na volta iria passar no cabeleireiro: hidratação, luzes, escova e talvez até implante de cabelo, queria ficar com um lindo cabelo comprido, embora tivesse cortado bem curto há menos de um mês, o gasto não a assustava, Mendonça estava abonado, suas transações na polícia the garantiam um bom rendimento (Ferréz, 2014, p. 91, grifo nosso).

No trecho citado, o procedimento permite o compartilhamento da indiferença da corrupção policial na classe média. Contudo, o discurso indireto livre não serve apenas para denunciar uma determinada realidade. Vide a descrição de José Antônio:

José Antônio continua subindo a viela e lhe vem à mente Juliana com seus 13 aninhos, bem magrinha e com o cabelo longo, naquela época suas brigas eram somente pelo dinheiro da mistura que Juliana pegava para comprar doces, pensava como ela era gostosinha, cheirava a neném, ele adorava colocar na sua bunda. Ah!, sua bunda, como era lisinha e redondinha, mas agora o tempo havia agido, e com uma força repentina, Juliana havia engordado, seu cabelo ficou seco, meio pastoso, meio gorduroso, sua boca era tão linda, e tinha um gostinho de hortelã, bem diferente de hoje com aquele sebinho nos cantos dos lábios, sempre ressecada e quase nunca com os dentes escovados. José Antônio suspira fundo, coloca as mãos no bolso e pega em alguns papéis, e vê que são as promissórias que teve que assinar pra internar sua irmã que estava à beira da morte por causa dos rins, José Antônio ri quando vê que está começando a chover, e sabe que Deus é tão bom que só não o mata com um relâmpago porque um pai não mata o filho (Ferréz, 2014, p. 26, grifo nosso).

\footnotetext{
${ }^{9}$ Lembremos que nesse romance há um narrador onisciente, que frequentemente recorre ao discurso indireto livre, e um narrador-personagem, Calixto, o protagonista.
} 
Como na citação em que se aborda a desilusão dos efeitos do tempo na vida conjugal, são muitos os trechos assinados concomitantemente por narrador e personagem em que se descortinam angústias, dilemas, sonhos, devaneios, ambições e opiniões de quem é representado. Por esse motivo, tal estratégia convém a concepções fora dos estereótipos:

Paulo morava num lugar onde ninguém se respeitava, assim ele acreditava, pois via os moradores jogarem lixos no córrego e dias depois estarem apavorados tirando os móveis de casa, pois o córrego transbordava e acabava invadindo suas casas, ao seu ver a falta de respeito era com eles próprios. Os pais bebendo o dia inteiro e jogando fora o que deveriam ser preciosos momentos de convivência com os filhos, então os pequenos ficavam brincando nos caça-níqueis, enquanto outros preferiam ficar dançando o já famoso forró do bar do Neco, todo dia era dia de festa e todo dia era dia de ver o álcool anestesiar homens, mulheres, idosos e até crianças, o sereno caía lentamente, o forró varava a madrugada, e o desgosto dominava de ponta a ponta uma viela, em todos uma dor de saudade, em todos a falta de algo que não sabiam bem o que era, em todos o fascínio da noite e o medo de chegar em casa e sem sono pensarem em suas vidas (Ferréz, 2014, p. 51, grifo nosso).

Convivendo com criminosos, Paulo é leitor de clássicos da literatura como Anton Tchekhov, Herman Hesse e Máximo Gorki, ratificando que outras trajetórias para o sujeito periférico são possíveis. Seria este um paradoxo: simultaneamente, afirma-se e nega-se a comunidade, pois o mundo letrado, que possibilita a enunciação de dentro por escritores como Paulo Lins, é também um instrumento, de acordo com Ángel Rama (1998), utilizado historicamente para afiançar a posse do território latino-americano? A problemática desfaz-se quando percebemos o poder de inclusão do narrador, consequência da incorporação de novos horizontes de expectativa ao texto, para remontarmos ao conceito de Jauss (1994). Já na segunda edição de sua primeira prosa longa, ainda em 2000, na dedicatória modificada, há o indicativo de que podem haver outros interlocutores: "Querido sistema, você pode até não ler, mas tudo bem, pelo menos viu a capa" (2013, p. 11). Com a publicação de Manual prático do ódio pela Planeta, uma grande editora, pressupõe-se que a obra lhe é igualmente necessariamente endereçada. Agora, ao contrário do romance de 30 - o qual até podia tematizar os oprimidos, mas cujos leitores eram das classes média e alta brasileiras -, o narrador de Ferréz prevê o leitor periférico, com pouca ou nenhuma escolaridade, e o historicamente favorecido. Ao não eliminar o 
horizonte de expetativas do leitor majoritariamente branco e sabidamente abonado, este é exposto como mais um elemento da engrenagem opressora do sistema:

Na mesma calçada passava Rodrigo, aluno do Colégio São Luís, localizado nos Jardins, o aluno passou despercebido, pois tinha trocado o uniforme por roupas mais simples para ir embora para casa, todos na escola passaram a adotar a prática depois que alguns colegas foram assaltados no percurso entre a casa e a escola, as vítimas eram sempre jovens de 14 a 16 anos, e os executores dos furtos também tinham a mesma idade, a única diferença entre os jovens que roubavam e os roubados é o muro social que divide o país (Ferréz, 2014, p. 32).

Se o público real amplia-se, o horizonte de expectativa do leitor construído no texto não fica para trás. Logo, o tom pedagógico do narrador presente em Capão pecado tem que ser revisto em Manual prático do ódio. O relato funcionaria então como um espelho do que esse novo leitor representa enquanto agente social. $\mathrm{O}$ que poderia ser entendido como denúncia passa a ser, por que não, acusação por omissão. Para tanto, um olhar de dentro, ancorado numa determinada localidade, transita entre outras, todas atreladas à exploração de classe:

Enquanto isso, Hudson escolhia no cardápio o prato mais caro. Pele clara, olhos verdes, cabelo ralo e roupas leves, estava com muita fome, a reunião pela venda da cocaina havia sido estressante, principalmente quando o cliente pediu mais tempo para o próximo pagamento, mas o dinheiro já estava no carro, não sabia se mandaria seu pequeno para a Disney novamente, ou se faria a vontade de sua esposa e iriam todos para a França, talvez os dois, o dinheiro era muito, e a reforma da última casa já estava finalizada, talvez quando voltasse das férias comprasse uma agência de turismo, aí sim ficaria perto do prazer o tempo inteiro. Pensou em chamar o gerente, em perguntar se o restaurante estava à venda, a comida não demorou a chegar, comia rapidamente, a carne estava um pouco malpassada, ao seu lado notou um menino de rua passando, o garoto trazia um maço de rosas nos braços, jurou para si mesmo não almoçar mais naquele restaurante, só tinha dois seguranças na porta, mastigou com desgosto quando viu que passou outro moleque ao seu lado, Hudson pediu o melhor vinho, e sabia como a venda do pó contribuía para todo aquele caos que ele sempre notava, mas para se eximir da culpa pensava na cidade como uma grande selva 
onde ele era com certeza um dos predadores, pois nunca teria vocação para ser a presa, também quem podia julgá-lo, o próprio distribuidor era um membro do Estado, devidamente votado e eleito, o seu papel era menor, fazer a pequena divisão dos setores, era uma questão de mercado, enquanto bebia o vinho, chegava à conclusão de que as drogas não eram o problema, o grande mal devia ser a loucura do ser humano, o celular tocou, deveria sair dali o mais breve possivel, faltou coca numa delegacia da Zona Norte, o delegado fez nova encomenda (Ferréz, 2014, p. 57, grifo nosso).

A reforma da casa, a indiferença com o garoto de rua ao lado do desejo de reenviar os filhos à Disney, o vinho caro a beber e as ramificações do tráfico no Estado elucidam a usurpação, sua desfaçatez e impunidade. Porém, outros abusos não são identificados com igual clareza, cabendo ao leitor distinguir em que consiste a exploração:

Levantou toda lambuzada de baba, ele pediu para que ela abaixasse a cabeça um pouco, Vânia virou a cabeça ficando de frente pra ele, Régis se levantou e olhando-a nos olhos cuspiu em sua boca, ela tentou cuspir e ele mandou que ela engolisse, obedeceu, ele deu alguns tapas em seus seios e ordenou que ela viesse de costas, veio, seus cabelos negros estavam totalmente molhados pelo champanhe, Régis puxou a calcinha de tigre para uma banda da nádega e introduziu o que ela apelidara de tomahawk, uma referência ao poderoso míssil americano, ela não havia se acostumado com o tamanho do seu pau, apesar de já transarem havia muito tempo, mas se reclamasse, sabia que ele aumentaria o ritmo, homem é assim, pensava ela, gosta de ver a gente sofrer (Ferréz, 2014, p. 42).

O fato de o narrador estar umbilicalmente ligado ao espaço o torna um pedagogo de como se dão algumas relações na periferia, mas não lhe capacita a discriminar tudo. O caso das mulheres é particularmente exemplar. $\mathrm{O}$ abuso sexual que sofre Vânia, amante de Régis, não é explicitado como outras injustiças ou suas implicações. A crítica é mais sutil, pois presente na descrição minuciosa do ato sexual, em que o homem é o ser que manda; e a mulher, quem obedece. $\mathrm{O}$ sexo não apresenta nem romantismo nem erotismo. O racionalismo do ato faz do outro um objeto a ser consumido e torna as ações mecânicas. $\mathrm{Na}$ sequência temos a descrição do cotidiano de Eliana: 
Desligou as duas bocas do fogão que estavam em uso, retirou o macarrão da panela e o lavou, pegou uma terceira panela e juntou o molho ao macarrão, mexeu bem, foi ao armário pegar o queijo ralado, colocou tudo em cima da mesa e sentindo que iria ser abraçada e domada a qualquer momento, foi para o quarto, fechou a porta que dava para a sala, deitou-se na cama, sentiu as mãos a lhe envolver as costas, o abraço, o ar mais gelado, olhou para o travesseiro ao lado e o viu abaixar, qual fosse uma cabeça a pousar nele, Eliana fechou os olhos e disse baixinho para sua companheira indesejável: - Vem, solidão (Ferréz, 2014, p. 44).

A descrição minuciosa de cada ação da mãe de família traída e abandonada, cuja monotonia lembra a relação sexual entre o marido e a amante, ganha contornos melancólicos quando a imagem da solidão, única companhia, deita-se a seu lado. A resignação é a marca da tirania de gênero. Por fim, o caso de Aninha:

Foi para casa, tirou o pacote da sacola, desembrulhou, retirou o vestido e, tirando a blusa azul de botões que estava usando, colocou o vestido por cima da calça mesmo, se sentiu bem e foi olhar-se no espelho, viu que tinha que tirar a calça jeans, mas preferiu deixar, pois não usaria o vestido agora, se posicionou em frente ao espelho novamente e ficou quieta por vários minutos, levou a mão direita aos lábios e os tocou, notou que estavam secos, lembrou-se de que não usava batom há meses, será que havia perdido toda a vaidade? Decidiu que na próxima vez que fosse a Santo Amaro iria comprar um estojo de maquiagem, afinal Aninha não atraía mais ninguém, e quando a noite começava a cair ela tentava fugir de alguns sentimentos, mas nem o álcool, nem a maconha conseguiam afastá-la daquelas ideias de um dia ter alguém abraçadinho na cama, de um dia ter alguém brincando correndo atrás dela no parque, de ter alguém que cuidasse de cada detalhe de seu corpo, na verdade sempre que chegava a noite, Aninha sentia uma imensa falta de algo que ela nunca teve e não sabia bem o que era, Aninha jamais poderia explicar, como sentir falta do que não teve, mas sentia. Aninha sabia que homem bundão ela não iria admitir, mas também não queria um cara que nem seus parceiros, queria alguém sensível, alguém que lhe perguntasse o que havia feito no dia anterior, que se importasse a cada nova espinha que nascesse, a cada espirro que desse (Ferréz, 2014, p. 74-75). 
Única mulher do bando de Régis, Aninha aparece isolada por não se adequar a nenhum padrão estabelecido no território em que transita. Não é feminina o suficiente para ser cobiçada pelos homens, ao mesmo tempo que seu ofício não lhe permite vestir-se como gostaria, nem conhecer outros homens que não sejam criminosos. Estes, por sinal, também não lhe interessam. Em um universo profissional heteronormativo, ser do sexo feminino interdita qualquer expressão gestual, comportamental, discursiva e de indumentária que não seja masculinizada. Entrar no mercado de trabalho do crime implica, para a mulher, anular-se enquanto identidade autônoma e revogar uma vida social longe da carreira. São privações extraordinariamente mais drásticas que as de Régis, é claro.

\section{Considerações finais}

Ao restringirmo-nos a leituras documentalistas, sociológicas ou antropológicas, identificando na autodenominada literatura marginal apenas a transcrição de uma realidade, uma contribuição de classe ou uma façanha digna de estudo, fazemos da interpretação das obras o que as classes mais abastadas perpetram com os habitantes da periferia: segregá-los em guetos e castrar seus discursos.

Tentando esquivar do que compreendemos como um problema hermenêutico, em Capão pecado vemos o surgimento de um narrador à margem. Sua existência prevê um novo leitor: com quem compartilha capitais simbólicos; que está também do lado de dentro; e que não necessariamente tem o hábito da leitura, acesso ao livro ou qualquer incentivo governamental à educação. Em Manual prático do ódio, incorpora-se o leitor de sempre, distante da pobreza, majoritariamente ignorante quanto a esta, semelhante ao brasileiro do sul e sudeste que desconhecia o regionalismo dos anos 1930. Para essa junção de leitores, conjuga-se uma tradição literária e uma local, em que a oralidade talvez seja a marca mais evidente.

A grande contribuição do romance, entretanto, encontra-se no nível narrativo. Ao perfilar distintas trajetórias, expõe-se a opressão e a dominação sobre o ser periférico, as quais são reproduzidas por este entre seus pares. A trama descortina uma pirâmide social perversa, na qual quem lucra sai ileso, protegido em um bairro de luxo, degustando seu vinho amadeirado. Todos os outros pagam o preço, em cadeia. 
Bandido experiente usurpa novato; assassino sanguinário, indivíduo de conceito; polícia, morador da comunidade; criminoso, comerciante; branco, negro; pastor, crente; homem, mulher; adulto, criança. Assim, é através da estrutura que se constrói a verdadeira denúncia: as consequências da lógica vil e desumanizada do capital. Contada de dentro, as ações e reações de cada uma das personagens apontam o dedo para a tragédia do sistema atroz em que vivemos, do qual não somos apenas cúmplices, segundo as palavras acertadas da voz moralista, mas atores.

\section{Referências}

CAMARGO, Luís Gonçalves Bueno de (2001). Uma história do romance brasileiro de 30. $944 \mathrm{f}$. Tese (Doutorado em Teoria e Historia Literária) - Universidade Estadual de Campinas, Campinas.

CARVALHAL, Thiago José Moraes (2014). No sentido (de) da(r) margem (à literatura e à música): rap, cumbia villera, literatura marginal e realismo atolondrado. 116 f. Dissertação (Mestrado em Letras Neolatinas) - Universidade Federal do Rio de Janeiro, Rio de Janeiro.

DALCASTAGNÈ, Regina (2005). A personagem do romance brasileiro contemporâneo: 1990-2004. Estudos de Literatura Brasileira Contemporânea, Brasília, n. 26, p. 13-71, jul./dez.

Damascena, Alexandre Silva (2015). A literatura a partir do território: a relação entre forma e conteúdo em Ferréz. 102 f. Dissertação (Mestrado em Letras Vernáculas) - Universidade Federal do Rio de Janeiro, Rio de Janeiro.

FERRÉZ (2000). Capão Pecado. São Paulo: Labortexto.

FERRÉZ (2003). Determinação. São Paulo: R.B. Estúdio. CD. Disponível em: https://www.youtube.com/watch?v=nnYpiXu9O3U. Acesso em: 9 mar. 2016.

FERRÉZ (2005a). Capão pecado. São Paulo: Objetiva.

FERRÉZ (2005b). Manifesto de abertura: literatura marginal - Terrorismo literário. In: FERRÉZ (Org.). Literatura marginal: talentos da escrita periférica. Rio de Janeiro: Agir.

FERRÉZ (2011). Entrevista para o site Canto dos Livros. Disponível em: http://ferrez.blogspot.com.br/2011/07/entrevista.html. Acesso em: 9 mar. 2016.

FERRÉZ (2012). Deus foi almoçar. São Paulo: Planeta. 
FERRÉZ (2014). Manual prático do ódio. E-book. Rio de Janeiro: Planeta.

HOLLANDA, Heloísa Buarque de (s.d.). A questão agora é outra. Disponível em: <https://goo.gl/0VrBrr>. Acesso em: 9 mar. 2016.

JAUSS, Hans Robert (1994). A história da literatura como provocação à teoria literária. Tradução de Sérgio Tellaroli. São Paulo: Ática.

JESUS, Carolina Maria de (1993). Quarto de despejo: diário de uma favelada. São Paulo: Ática.

LINS, Paulo (2012). Cidade de Deus. E-book. São Paulo: Planeta.

MONGIM, Luciana Marquesini (2012). Territorialidades marginais e construção est(ética): Capão Pecado e Manual prático do ódio, de Ferréz. 197 f. Dissertação (Mestrado em Letras) - Universidade Federal do Espírito Santo, Vitória.

Nascimento, Érica Peçanha do (2006). "Literatura marginal": os escritores da periferia entram em cena. 203 f. Tese (Doutorado em Antropologia Social) Universidade de São Paulo, São Paulo.

PATROCÍNIO, Paulo Roberto Tonani do (2010). Escritos à margem: a presença de autores de periferia na cena literária brasileira. $222 \mathrm{f}$. Tese (Doutorado em Letras) - Pontifícia Universidade Católica do Rio de Janeiro, Rio de Janeiro.

RAMA, Angel (1998). A ciudad letrada. Montevidéu: Arca.

REGO, José Lins do (2014). Menino de engenho. Rio de Janeiro: José Olympio.

ROCHA, João Cezar de Castro (2005). The dialectic of marginality: preliminary notes on Brazilian contemporary culture. Oxford: Centre for Brazilian Studies, University of Oxford, p. 1-39. (Working Paper, n. 62)

ROCHA, João Cezar de Castro (2007). A guerra de relatos no Brasil contemporâneo. Ou: a "dialética da marginalidade". Revista do Programa de Pós Graduação em Letras, Santa Maria, n. 32, p. 24-70, maio.

Rodriguez, Benito Martinez (2004). O ódio dedicado: algumas notas sobre a produção de Ferréz. Estudos de Literatura Brasileira Contemporânea, Brasília, n. 24, p. 53-67, jul./dez.

SILVA, Mário Augusto Medeiros da (2011). A descoberta do insólito: literatura negra e literatura periférica no Brasil (1960-2000). 448 f. Tese (Doutorado em Sociologia) - Universidade Estadual de Campinas, Campinas.

SOUZA, Renato (2010). O "caso Ferréz": um estudo sobre a nova literatura marginal. 181 f. Dissertação (Mestrado em Letras) - Universidade Estadual Paulista, Assis. 
SPIVAK, Gayatri Chakravorty. (2010). Pode o subalterno falar? Tradução de Regina Goulart Almeida, Marcos Pereira Feitosa e André Pereira Feitosa. Belo Horizonte: Editora UFMG.

SÜSSEKIND, Flora (2003). Desterritorialização e forma literária. Literatura brasileira contemporânea e experiência urbana. Literatura e Sociedade, São Paulo, n. 8.

VELlOSO, Luciana Mendes (2007). Capão Pecado: sem inspiração para cartão postal. 155 f. Dissertação (Mestrado em Letras) - Universidade Federal De Minas Gerais, Belo Horizonte.

ZIBORDI, Marcos Antonio (2004). Jornalismo alternativo e literatura marginal em Caros Amigos. 193 f. Dissertação (Mestrado em Literatura) - Universidade Federal do Paraná, Curitiba.

Recebido em agosto de 2016.

Aprovado em outubro de 2016.

\section{resumo/abstract/resumen}

\section{Reflexões quanto à literatura marginal brasileira: comparando Ferréz a sua tradição literária}

Vinícius Gonçalves Carneiro

A denominação "literatura marginal" vem se transformando na tradição literária brasileira ao longo das décadas, associando-se a uma gama de estilos, textos e autores. Nos últimos anos, está mais ligada a uma literatura produzida na periferia e que compreende como público setores da sociedade brasileira que nunca foram alvo do mercado editorial. Textualmente, caracteriza-se por apresentar vozes pouco presentes na nossa tradição literária. Todavia, o adjetivo "marginal" é ainda escorregadiço, associando-se a determinados autores e obras talvez mais pelo fato de o utilizarem em manifestos e entrevistas do que por existirem textos com características reconhecíveis como "marginais". O presente estudo pretende aproximar-se de uma descrição dessa literatura ao se debruçar em publicações como Manual prático do ódio, de Ferréz. Trata-se, portanto, de uma proposta descritiva e comparativa cujo objetivo é traçar alguns elementos pertinentes à literatura conhecida como marginal, assim a diferenciando de outras marginalidades da nossa história literária.

Palavras-chave: literatura marginal, oralidade, representação do subalterno, Ferréz. 


\title{
Reflections on Brazilian marginal literature: comparing Ferréz to his literary tradition
}

\author{
Vinícius Gonçalves Carneiro
}

The concept "marginal literature" in Brazilian literature has changed in recent decades. Nowadays, it is synonymous with a specific writing style, certain texts and select authors. Over the last years, the concept is mostly associated to works produced in urban the peripheries, and its readership is primarily composed of people normally disregarded by the publishing market. Thematically, these works represent the voices of those who are mostly absent from Brazil's literary panorama.. However, the adjective "marginal" is not easy to define. Often the concept is associated with specific authors and works that employ the term in manifestos and interviews, rather than to describe what might be the aesthetic characteristics of "marginal" literature. This essay intends to give a detailed account of this literature in works such as Practical Manual of Hate by Ferréz. It is, therefore, a descriptive and comparative project, which hopes to identify some traces linked to a well-established literary genre that is distinct from other Brazilian literary marginalities.

Keywords: marginal literature, orality, representation of the subaltern, Ferréz.

\section{Reflexiones sobre la literatura marginal brasileña: Ferréz y su tradición literaria}

\section{Vinícius Gonçalves Carneiro}

El concepto de "literatura marginal" cambia en la tradición literaria brasileña a lo largo de las décadas, puesto que se asocia con un amplio espectro de estilos, textos y autores. En los últimos años, se vincula más a una literatura producida en la periferia de las grandes ciudades y cuyo público es formado por sectores de la sociedad brasileña que nunca interesaron el mercado editorial. Podemos decir que la "literatura marginal" se caracteriza por hacer oír voces casi siempre ausentes en nuestra tradición literaria. Sin embargo, no resulta fácil definir el adjetivo "marginal", ya que se relaciona con autores y obras tal vez más debido a su uso en manifiestos y entrevistas que a características textuales "marginales". Este estudio intenta hacer una descripción de esta literatura a partir de publicaciones tales como Manual práctico del odio, de Ferréz. Se trata, por lo tanto, de una propuesta descriptiva y comparativa cuyo objetivo es identificar algunos rasgos pertenecientes a la literatura actualmente conocida como "marginal", así como distinguirla de otras marginalidades de nuestra historia literaria.

Palabras clave: literatura marginal, oralidad, representación del subalterno, Ferréz. 